\title{
Capital Flows and Real Exchange Rate Overvaluation - A Chronic Ailment: Evidence from Pakistan
}

\section{Hamna Ahmed *}

\begin{abstract}
The objective of this study is twofold: (i) to estimate the equilibrium real exchange rate (RER) from a long-run perspective and calculate the degree of overvaluation for the period 1972-2007, and (ii) to test the Dutch Disease hypothesis concerning the effect of capital flows on the RER in Pakistan. Based on various macroeconomic fundamentals suggested in economic literature by Edwards (1988, 1989, 1994), Elbadawi (1994), and Montiel (1997), the equilibrium RER is estimated as a function of the terms of trade, government spending, degree of openness, workers' remittances, foreign direct investment (FDI) flows, and foreign economic assistance. In view of this study's long-term focus, all unsustainable and temporary flows are filtered out to obtain an accurate misalignment index. Estimation results are in line with theoretical postulations: an increase in capital flows, government spending on nontradable goods and terms of trade improvement are consistent with an appreciation of the RER, while an increase in the degree of openness is expected to depreciate the RER. Findings suggest that the RER suffers from chronic overvaluation in Pakistan. In spite of filtering out unsustainable and temporary flows, overvaluation increased from $0.75 \%$ in 2001 to 22.9\% in 2007. A sharp rise in FDI flows (between 2005 and 2007) and an increase in remittances (between 2002 and 2007) are among the main factors that have contributed to this persistent overvaluation. Results also suggest that the Dutch Disease hypothesis holds in the case of Pakistan.
\end{abstract}

JEL Classification: F10, G00, E22.

Keywords: Real exchange rate, capital inflow, overvaluation, Pakistan.

\section{Introduction}

The significance of the exchange rate as a crucial policy fundamental with profound implications for the macro-economy, motivates this study. The

\footnotetext{
${ }^{*}$ Research Associate at the Lahore School of Economics, Pakistan.
} 
exchange rate can impact the economy through two potential channels: (i) by influencing a country's macroeconomic stability, and (ii) by affecting the size of its tradable sector. Unfortunately, Pakistan has fared poorly on both counts. In the past, there have been recurrent episodes of dwindling foreign currency reserves, persistent deficits, and severe macroeconomic crises (Table-1). According to the literature, a current account deficit to gross domestic product (GDP) ratio in excess of 5.0 is largely considered unsustainable. During the 1990s, there were two particular instances of a sharp deterioration in the current account deficit: (i) between 1992 and 1993, ${ }^{1}$ and between 1995 and $1996 .{ }^{2}$ While there was a significant improvement in Pakistan's external position between 2000/01 and 2003/04, the current account deficit has been deteriorating since 2005. According to the State Bank of Pakistan's annual report, the current account deficit expanded by approximately $104 \%$ over the last year $(2007$ - 2008) and reached a record historical peak of US\$14 billion. More than $80 \%$ of this increase has been due to an increasing trade deficit which can be attributed to the following factors: (i) a falling export-to-GDP ratio, and (ii) a massive increase in imports as a percentage of GDP due to (a) an increase in domestic demand, and (b) an unprecedented rise in global oil and commodity prices-the expansion in the oil trade deficit alone explains about $38 \%$ of the overall deterioration in current account between 2007 and $2008 .^{3}$

Table-1: Trade and Current Account Deficits over Time (1982/83 to $2007 / 08)$

\begin{tabular}{ccccc}
\hline Year & $\begin{array}{c}\text { Current Deficit } \\
\text { (\$ million) }\end{array}$ & $\begin{array}{c}\text { Trade Deficit } \\
\text { (\$ million) }\end{array}$ & $\begin{array}{c}\text { Current Deficit } \\
\text { (\% of GDP) }\end{array}$ & $\begin{array}{c}\text { Trade Deficit } \\
\text { (\% of GDP) }\end{array}$ \\
\hline 1982 & -517 & $-2,989$ & -1.80 & -10.43 \\
1983 & -997 & $-3,324$ & -3.19 & -10.64 \\
1984 & $-1,680$ & $-3,552$ & -5.28 & -11.16 \\
1985 & $-1,236$ & $-3,042$ & -3.64 & -8.97 \\
1986 & -719 & $-2,294$ & -2.03 & -6.48 \\
1987 & $-1,682$ & $-2,557$ & -4.32 & -6.56 \\
1988 & $-1,934$ & $-2,573$ & -5.44 & -7.24 \\
\hline
\end{tabular}

\footnotetext{
${ }^{1}$ During the financial year (FY) 1993, the current account deficit was caused by a surge in automobile imports on account of the 'yellow cab scheme.'

2 During FY1996 and FY1997, contracts with independent power projects pushed up power generating machinery imports and thereby the current account deficit.

${ }^{3}$ State Bank Annual Report (2007/08).
} 


\begin{tabular}{|c|c|c|c|c|}
\hline Year & $\begin{array}{c}\text { Current Deficit } \\
\text { (\$ million) }\end{array}$ & $\begin{array}{l}\text { Trade Deficit } \\
\text { (\$ million) }\end{array}$ & $\begin{array}{c}\text { Current Deficit } \\
\text { (\% of GDP) }\end{array}$ & $\begin{array}{c}\text { Trade Deficit } \\
\text { (\% of GDP) }\end{array}$ \\
\hline 1989 & $-1,891$ & $-2,485$ & -5.34 & -7.02 \\
\hline 1990 & $-1,057$ & $-1,260$ & -2.28 & -2.71 \\
\hline 1991 & $-1,346$ & $-2,236$ & -2.76 & -4.58 \\
\hline 1992 & $-3,688$ & $-3,267$ & -7.13 & -6.32 \\
\hline 1993 & $-1,965$ & $-2,000$ & -3.77 & -3.83 \\
\hline 1994 & $-2,484$ & $-2,537$ & -4.07 & -4.16 \\
\hline 1995 & $-4,575$ & $-3,704$ & -7.17 & -5.80 \\
\hline 1996 & $-3,846$ & $-3,145$ & -6.10 & -4.99 \\
\hline 1997 & $-1,921$ & $-1,867$ & -3.10 & -3.01 \\
\hline 1998 & $-2,381$ & $-2,085$ & -3.82 & -3.35 \\
\hline 1999 & $-1,195$ & $-1,471$ & -1.95 & -2.40 \\
\hline 2000 & -513 & $-1,269$ & -0.71 & -1.76 \\
\hline 2001 & 1,338 & -294 & 1.85 & -0.41 \\
\hline 2002 & 3,165 & -444 & 3.80 & -0.53 \\
\hline 2003 & 1,314 & $-1,208$ & 1.34 & -1.23 \\
\hline 2004 & $-1,534$ & $-4,514$ & -1.40 & -4.12 \\
\hline 2005 & $-5,015$ & $-8,464$ & -3.95 & -6.67 \\
\hline 2006 & $-6,878$ & $-9,711$ & -4.79 & -6.76 \\
\hline 2007 & $-14,016$ & $-15,286$ & -8.37 & -9.12 \\
\hline
\end{tabular}

Source: Economic Survey of Pakistan (1990-91), (1999-00), (2007-08).

Further, the growth of the tradable sector in Pakistan has been poor relative to the nontradable sector (Figure 1). Traditionally, only commodity producing sectors (agriculture, manufacturing, and mining) were defined as tradable while all others (construction, services, transport, and communications) were classified as nontradables. However, owing to technological improvements, services have now entered the sphere of the tradable sector, thus rendering somewhat abstract the conventional distinction between tradables and nontradables. Developing economies that are highly integrated in world markets have experienced this evolving nature of the tradable sector, but Pakistan seems to be an outlier as far as global trends are concerned. It is thus more appropriate to use the conventional 
definition to gauge the relative performance of these two sectors vis-a-vis each other. Given that the exchange rate can impact a country's growth potential through these two operative channels, an attempt to understand exchange rate behavior in Pakistan poses an interesting exercise that could provide useful insights from a policy perspective.

Figure 1: Relative Performance of Tradable and Nontradable Sectors (\%) (1980/81 to $2006 / 07)$

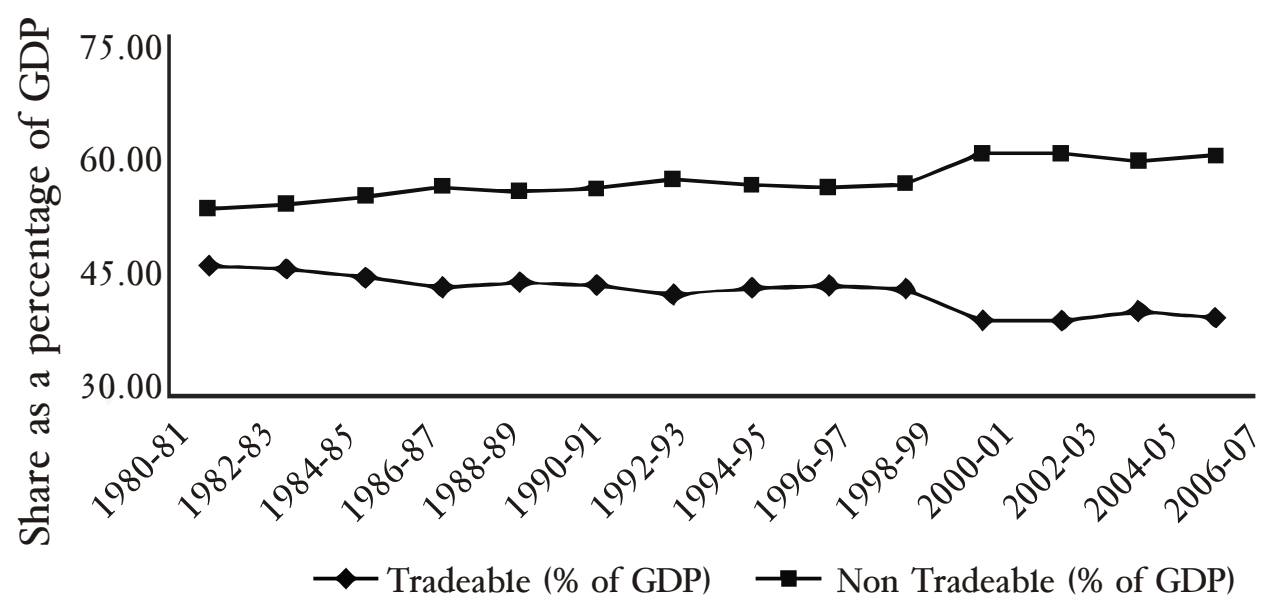

Source: Author's calculations based on Pakistan Economic Survey data (various issues)

A wealth of literature is devoted to understanding the behavior of exchange rates. Broadly speaking, it is possible to identify three distinct strands of empirical studies on exchange rates. The first set is concerned with analyzing the determinants of exchange rates [for developing countries, see Edwards (1989), Hinkle and Montiel (1999), Edwards and Savastano (2000), and Osbat and Schatz (2004); for Pakistan, see Chisti and Hassan (1993), Afridi (1995), and Siddiqui, Afridi, and Mahmood (1996)]. The second set deals with estimating misalignment by invoking some notion of an equilibrium exchange rate [see Elbadawi (1997), Janjua (2007), Hussain (2008), and Rodrik (2008)], while the third examines the implications of a misaligned exchange rate on economic activity [see Razin and Collins (1997), Domac and Shabsigh (1999), and Torres and Caglayan (2008)].

The objective of this study is twofold. As a first step, it is concerned with estimating the equilibrium real exchange rate (RER)-a measure which is subsequently compared with the actual rate in each period to establish the degree of exchange rate misalignment in Pakistan for the period 1972-2007. Misalignment refers to a situation in which the actual RER deviates from some notion of an 'ideal' exchange rate. Such a 
deviation can lead to two possible scenarios: (i) overvaluation-in which the actual RER is more appreciated than the 'ideal,' and (ii) undervaluation-in which the actual RER is more depreciated than the 'ideal.' Section IV looks at how nominal and real exchange rates have evolved in Pakistan over time, while Section VI undertakes empirical estimations of the degree of exchange rate misalignment.

In addition, this study is geared toward understanding the impact of capital flows on RER behavior in Pakistan. The direction of the relationship between capital flows and the RER is subject to controversy in economic literature. For instance, Corbo (1985) presents evidence in support of a mismanaged nominal exchange rate causing a sharp overvaluation of the peso, thereby attracting foreign capital in Chile, while others conclude a reverse causal link between capital flows and RERs, such that an increase in capital flows appreciates the RER [see Edwards and Morande (1988), Elbadawi and Soto (1994), Baffes, Elbadawi, and Connell (1997), and Hussain (2008)].

The remainder of the paper is organized as follows: Section II develops the backdrop for this study based on two arguments; (i) that exchange rate overvaluation is bad for growth, and (ii) that an unprecedented increase in capital inflows is a cause of disease rather than cure for the Pakistan economy's tradable sector. Section III lays down the theoretical framework for this study. Section IV provides a brief overview of how the exchange rate and other relevant macroeconomic fundamentals have evolved in Pakistan over time. Section V outlines the methodology used. Section VI deals with empirical estimation and results, and Section VII concludes the paper.

\section{Backdrop}

\section{Exchange rate overvaluation hampers growth}

The literature maintains universal consensus on the adverse link between exchange rate overvaluation and economic growth-a finding that is well in sync with the diverse experience of a range of developing countries, and strongly supported by cross-country statistical evidence. For instance, Razin and Collins (1997) develop misalignment indicators for a sample of 93 industrial and developing economies over 16- to 18-year periods since 1975, and conclude that a $10 \%$ overvaluation of a country's RER is likely to reduce per capita real growth rate by $0.6 \%$; however, they fail to establish a significant relationship between undervaluation and growth. Johnson, Ostry, and Subramanian (2007) compare Africa today with countries that have been

prone to similar institutional weaknesses in the past but managed to sustain 
high growth rates. The analysis suggests that a manufactured export-led strategy could help Africa to escape underdevelopment. In turn, such a development strategy must address two particular concerns: (i) micro-level institutions that affect the cost of exporting, and (ii) the need to avoid overvaluation of the exchange rate. Likewise, Easterly (2005) opposes exchange rate overvaluations by concluding that large overvaluations adversely impact economic growth; however, he remains skeptical about significant growth effects resulting from moderate exchange rate movements. In light of this well-established link between overvaluation and growth, studying exchange rate behavior in the context of a developing country like Pakistan can provide useful insights for understanding an important dimension of the erratic nature of Pakistan's growth experience.

\section{Capital flows - a disease or cure for Pakistan?}

Capital flows to Pakistan have been huge and persistent (Figure 2). Since 2000, capital flows have ranged between approximately 7 and $20 \%$ of GDP. ${ }^{4}$ This raises important questions about the impact of such flows on economic outcomes in Pakistan. An optimistic view of foreign capital inflows is that they are likely to augment national savings, promote investment, and accelerate growth in developing countries like Pakistan. However, Pakistan's actual experience deviates largely from theoretical predictions-the main reason for this irregularity between theory and experience lies in the nature of these flows. While capital flows have been large, they have essentially been unsustainable, temporary, and highly volatile in nature. Consequently, on the one hand these flows have contributed to stop-go cycles in economic growth while on the other, they have exerted appreciating effects on the RER and distorted the relative incentives to operate in the tradable relative to the nontradable sector. Therefore, this paper places special emphasis on the effect of capital flows on the RER to establish whether or not capital flows are a cause of disease for the tradable sector and thereby for economic growth in Pakistan.

\footnotetext{
4 Author's calculations are based on data from the Pakistan Economic Survey (various issues), and Handbook of Statistics, SBP (2005). Figures are based on three categories: (i) workers' remittances, (ii) foreign economic assistance, and (iii) FDI.
} 
Figure 2: Capital Flows over Time (1973-2008)

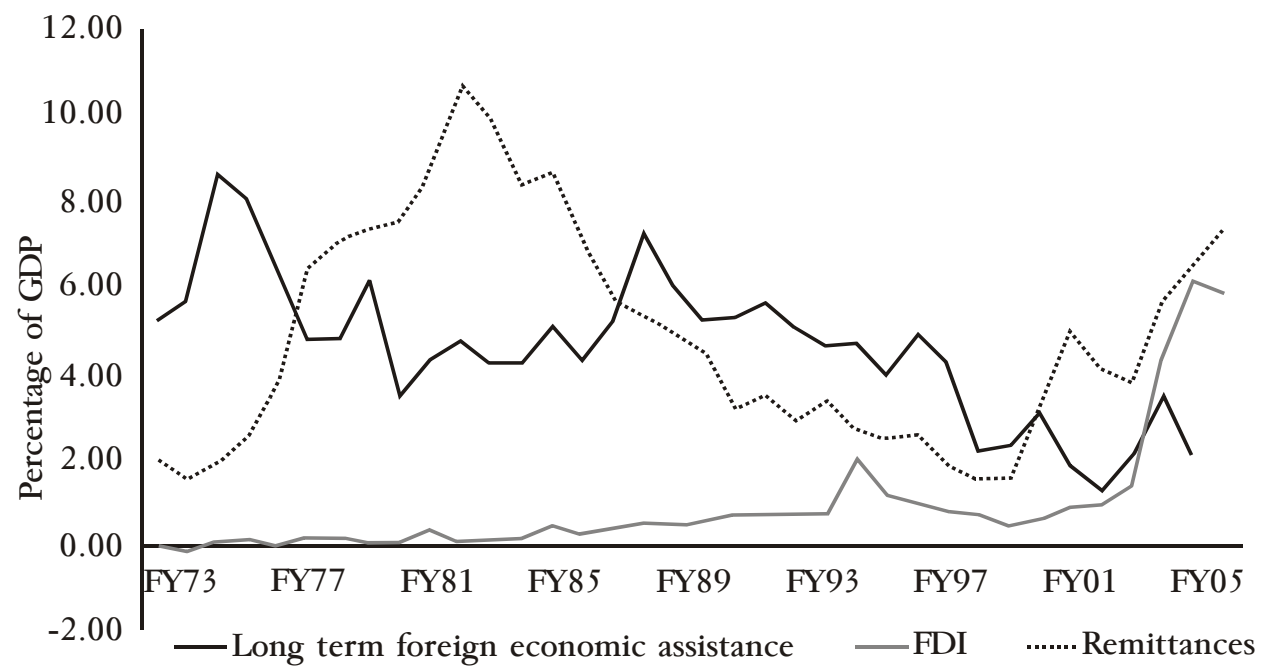

\section{Theoretical Framework}

A fundamental difficulty in studying exchange rate misalignment is that the equilibrium rate is not observable and hence must be based on some notion of an 'ideal.' The literature on defining such an 'ideal' varies significantly. The foremost approach to equilibrium RER determination employs purchasing power parity (PPP) theory, and dates back to Cassel's work in 1916. A trademark of this approach is to assume that the equilibrium exchange rate is a constant, time-invariant value for all periods. For instance, Cottani (1990), Ghura and Grennes (1993), and Domac and Shabsigh (1999) use an average of three highest values for the RER (denoting devaluation years) as a proxy for the equilibrium rate. This is done based on the assumption that devaluation usually follows a balance of payment crisis, and hence the RER is likely to be closer to equilibrium after devaluation occurs than otherwise. This approach can be criticized on two counts. One, contrary to theory, it assumes that the equilibrium RER is independent of other macroeconomic fundamentals. Two, it fails to account for the possibility that, as economic fundamentals change, the equilibrium RER may also exhibit variation over time. In light of these criticisms, a more recent strand of literature assumes the equilibrium RER to be a function of a set of underlying macroeconomic fundamentals and employs econometric estimation to obtain that equilibrium. This approach was first pioneered by Williamson (1983) and has been developed further by Edwards (1989), Elbadawi (1997), and Montiel (1999). In what follows, a theoretical framework underlying this approach will be laid out in detail.'

\footnotetext{
${ }^{5}$ The theoretical framework is based on the work of Baffes, Elbadawi, and O’Connell (1997).
} 


\section{Defining the RER}

For a small open economy with two sectors, a tradable and nontradable sector, the RER is defined as the relative price of tradable goods with respect to nontradable goods:

$$
E R=\frac{P_{T}}{P_{N}}
$$

where $\mathrm{P}_{\mathrm{T}}$ and $\mathrm{P}_{\mathrm{N}}$ are domestic price indices for tradables and nontradables, respectively. A major drawback of this definition is that it is difficult to calculate in practice. Most empirical studies resort to the following operational version of this definition:

$$
E R=\frac{P_{T}^{*}}{P_{N}}
$$

where $\mathrm{E}$ is the nominal exchange rate, defined as the number of units of domestic currency (Pakistan rupees) per unit of foreign currency (US dollar), while $\mathrm{P}_{\mathrm{T}}{ }^{*}$ denotes the foreign currency price of tradables. In practice, data limitations warrant the use of proxies for prices of tradables and nontradables. Among alternative price indices, the whole price index (WPI) is likely to be the most heavily weighted by tradables, while the consumer price index (CPI) is expected to be the most heavily weighted by nontradables. Consequently, the US whole price index is taken as a proxy for $\mathrm{P}_{\mathrm{T}}{ }^{*}$ while the domestic CPI is employed as a proxy for $\mathrm{P}_{\mathrm{N}}$ [see Ballasa (1990), Edwards (1990, 1989, 1988), Cottani (1990), and Domac and Shabsigh (1999)]. In light of the above discussion, the RER is defined as:

$$
E R_{i t}=\frac{E_{i t} W P I_{U S}}{C P I_{i t}}
$$

Given this definition, an increase in this ratio implies a real depreciation and hence an improvement in the country's international competitiveness, while a decrease implies a real appreciation or loss in international competitiveness.

\section{Specifying a Theoretical Model}

This section presents a simplified model for determining the equilibrium RER, ${ }^{6}$ which will form the basis of the empirical estimation undertaken in Section VI. Based on the premise that the RER is a function

${ }^{6}$ Montiel (1997) 
of a set of exogenous and policy-induced fundamentals, the long-run equilibrium RER is defined as that rate at which the economy is in internal as well as external balance. An internal balance holds when the markets for labor and nontraded goods clear. Mathematically, such a situation arises when the following condition is met:

$$
y_{N}(e)=c_{N}+g_{N}=(1-\theta) e c+g_{N}
$$

where $\mathrm{y}_{\mathrm{N}}$ is the total supply of nontraded goods under full employment, and $c, \theta, c_{N}$, and $g_{N}$ represent overall private consumption spending, the share of this spending on tradable goods, private spending on nontradable goods, and government spending on nontradable goods, respectively. External balance has been defined in numerous ways in the literature. For the purpose of this study, following Elbdawi (1997), Edwards (1989), and Rodriquez (1994), external balance is defined as holding when a country's net creditor position in world financial markets has reached steady-state equilibrium. Starting from a current account surplus given by:

$$
\dot{f}=b+z+r f=y_{T}(e)-g_{T}-(\theta+\tau) c+z+r f
$$

where $f$ is total net foreign assets, $b$ is the trade balance-the difference between domestic production of traded goods and the sum of government $\left(\mathrm{g}_{\mathrm{T}}\right)$ and private spending on these goods $(\mathrm{c})-\mathrm{Z}$ is net foreign aid received by the government, $r$ is the real yield on foreign assets, and $\tau$ measures transaction costs associated with private spending. External balance requires $f$ to reach a steady-state value in which case the right-hand side of equation (5) can be set to zero.

Further, the model can be extended to capture the dynamic nature of trade policy and terms of trade defined as follows:

$$
\frac{P_{X}}{P_{M}}=\frac{\phi}{\eta,} \quad \phi \equiv \frac{P_{X}{ }^{*}}{P_{M}{ }^{* \prime}} \quad \eta \equiv \frac{1+t_{M}}{1-t_{X}}
$$

where domestic terms of trade are defined as the ratio of the domestic prices of exports $(\mathrm{Px})$ and imports $(\mathrm{Pm}), \phi$ represents the external terms of trade, and $\eta$ summarizes the economy's trade policy stance as given by the extent of import taxes and export subsidies. If either $\phi$ or $\eta$ changes (in practice, both exhibit a dynamic nature), the analysis must incorporate the subsequent effects on the equilibrium RER. Setting the right-hand side of equation (5) to zero and combining equations (4), (5), and (6) yields an expression for the long-run relationship between the equilibrium RER and a set of exogenous and policy-induced fundamentals. 


$$
e^{*}=e^{*}\left(g_{N}, g_{T}, b, \phi, \eta, \tau^{*}\right)
$$

Pre-existing empirical studies on determining the equilibrium RER use some version of equation (7) and entail a context-specific choice of fundamentals to be included for calculating the equilibrium exchange rate. For instance, Edwards (1988) and Chishti and Hassan (1993) argue that, from a short-term perspective, both real factors (terms of trade, trade policy, government spending, capital flows, etc.) and monetary factors (domestic credit policy, fiscal deficit, etc.) are important determinants of the RER but that only real factors are important in the long run. Since this study adopts a long-run focus, monetary factors have not been included in attempts to estimate the RER.

The term 'misalignment' will be used to denote the gap between the actual RER in each time period (e) and equilibrium RER obtained from econometric estimates ( $\left.\mathrm{e}^{*}\right)$. For simplicity, equation (7) can be expressed as: ${ }^{7}$

$$
\ln \left(e_{T}^{*}\right)=\beta^{\prime} F_{t}^{P}
$$

where $e^{*}$ is the equilibrium RER, $t$ is the time period, $F$ is the vector of fundamentals that determine the RER, and $\beta$ is the vector of long-run parameters that determine the magnitude and direction of the relationship between the RER and fundamentals.

\section{The 'Dutch Disease' Dimension}

The concept underlying Dutch Disease theory goes back to the 1960s when natural gas was discovered in the Netherlands. On the one hand, this discovery led to windfall gains in national income; on the other, it had a negative impact on growth by adversely affecting the competitiveness of other non-booming tradable sectors in the Netherlands. Since then, this economic paradox has been termed 'Dutch Disease' in the literature. Within the framework of this study, the Dutch Disease hypothesis predicts that a large influx of capital flows will exert an appreciating affect on the RER. In turn, the nontradable sector will be influenced at the expense of the tradable sector via a 'spending' effect and a 'resource movement' effect ${ }^{8}$, as illustrated in Figure 3.

\footnotetext{
${ }^{7}$ Edwards (1989) and Montiel (1997).

${ }^{8}$ Cordon and Neary (1982).
} 
Figure 3: Dutch Disease and Capital Inflows

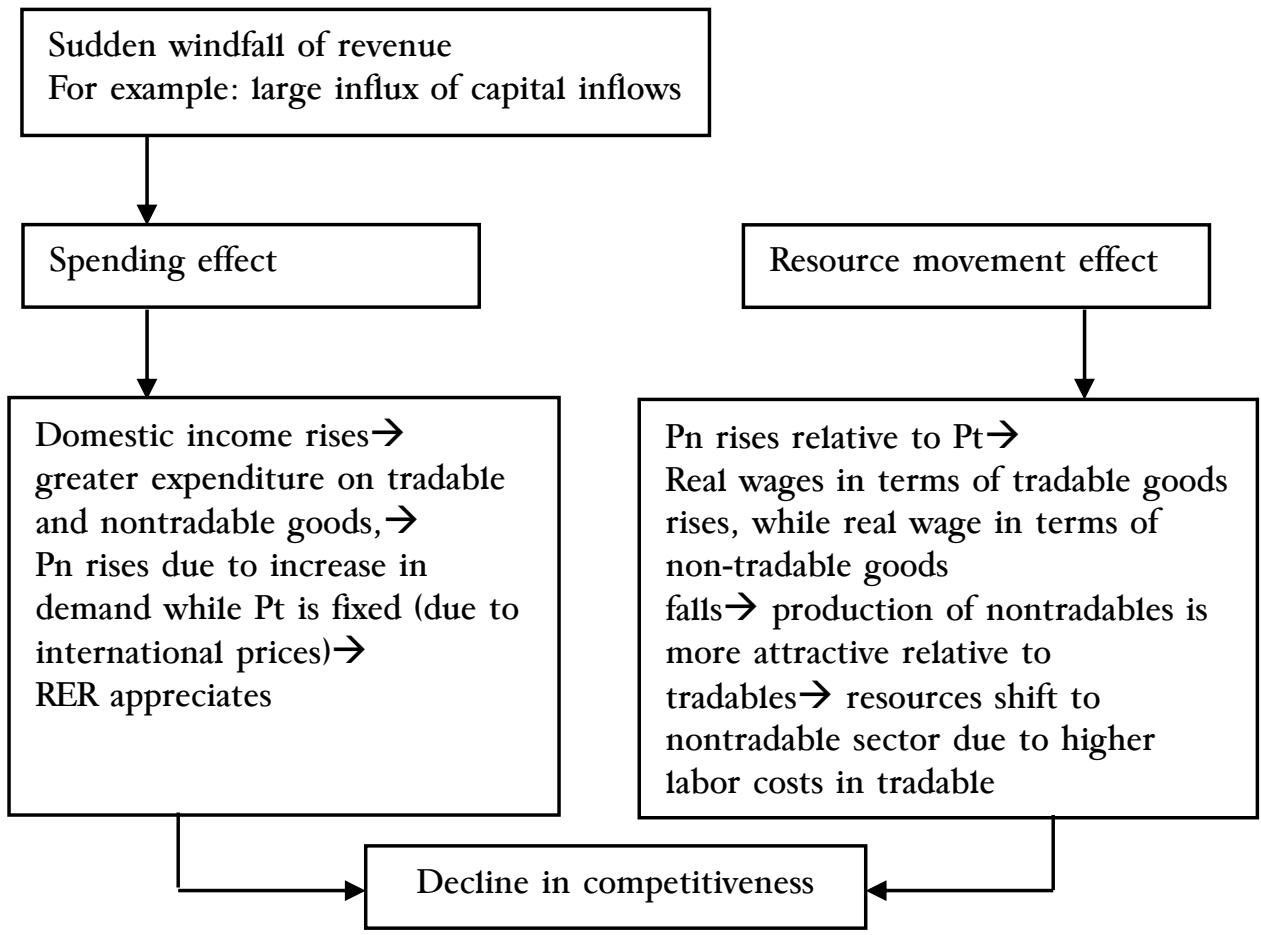

While prior work on the RER specific to Pakistan exists, it can be criticized on two grounds. One common shortcoming in existing studies is that all sorts of capital flows are lumped together in a single category to determine the RER. Since 'capital flows' is a balancing item in the balance of payment accounts, incorporating all categories irrespective of their nature (whether temporary or permanent, sustainable or unsustainable), is likely to dampen deviations between the actual and equilibrium RER and hence provide biased misalignment indicators. Hussain (2008) concludes that, on average, the RER was overvalued by a mere $1.7 \%$ over $2000-07$. Clearly, this seems to be a highly understated value given the large upsurge of capital flows post 9/11 and sharp increase in remittances from about $\$ 1$ billion in FY2001 to approximately $\$ 7$ billion in FY2008.'

A second basis for criticism stems from the type of econometric methodology employed by these studies, i.e., a simplistic regression analysis [Afridi (1995) and Hassan and Chishti (1993)]. Since most macroeconomic fundamentals are nonstationary, any conclusion drawn without examining time series properties of the underlying variables must be viewed with caution due to the inherent possibility of a spurious correlation.

\footnotetext{
${ }^{9}$ Handbook of Statistics, SBP (2005), and Pakistan Economic Survey.
} 
In light of these criticisms, this study contributes to the existing literature by placing special emphasis on capital flows in determining the equilibrium RER and by employing an estimation technique that is consistent with the underlying nature of variables in question. The former entails two aspects: (i) in view of this study's long-term focus, all kinds of unsustainable and temporary flows are filtered out to obtain an accurate misalignment index that is neither overstated nor understated, and (ii) it incorporates the 'Dutch Disease' dimension which warrants disaggregating capital flows into various categories based on the premise that the nature of capital inflow will determine the extent of RER misalignment. ${ }^{10}$

To this effect, six categories of capital flows were identified: ${ }^{11}$ worker's remittances under investment flows, portfolio and foreign direct investment (FDI) flows under foreign economic assistance, project-based lending and nonproject-based lending (both of which are long-term in nature), and short-term foreign economic assistance. To ensure that only sustainable flows are incorporated, long-term foreign economic assistance is filtered such that short-term flows and non-project aid flows are not included. Nonproject aid further includes subcategories like non-food aid, food aid, balance of payment support and relief aid (for Afghan refugees, earthquake relief assistance, etc.). For instance, in 2006, relief aid included earthquake relief assistance worth US\$915 million and relief for Afghan refugees worth US\$1 million. In 2007, relief aid included earthquake relief assistance worth US\$186 million and relief for Afghan refugees worth US\$3 million. ${ }^{12}$ Clearly, such flows represent one-off payments, are unsustainable, and hence validate the filtering of data. Figure 4 illustrates project and nonproject lending as a percentage of GDP. The sharp and frequent kinks in non-project lending lend merit to filtering out these flows when examining their impact on the equilibrium RER from a long-run perspective.

\footnotetext{
${ }^{10}$ Figure I, Appendix A.

${ }^{11}$ Handbook of Statistics, SBP (2005).

${ }^{12}$ Pakistan Economic Survey 2006-07.
} 
Figure 4: Project and Nonproject Lending (percent) (1971-2007)

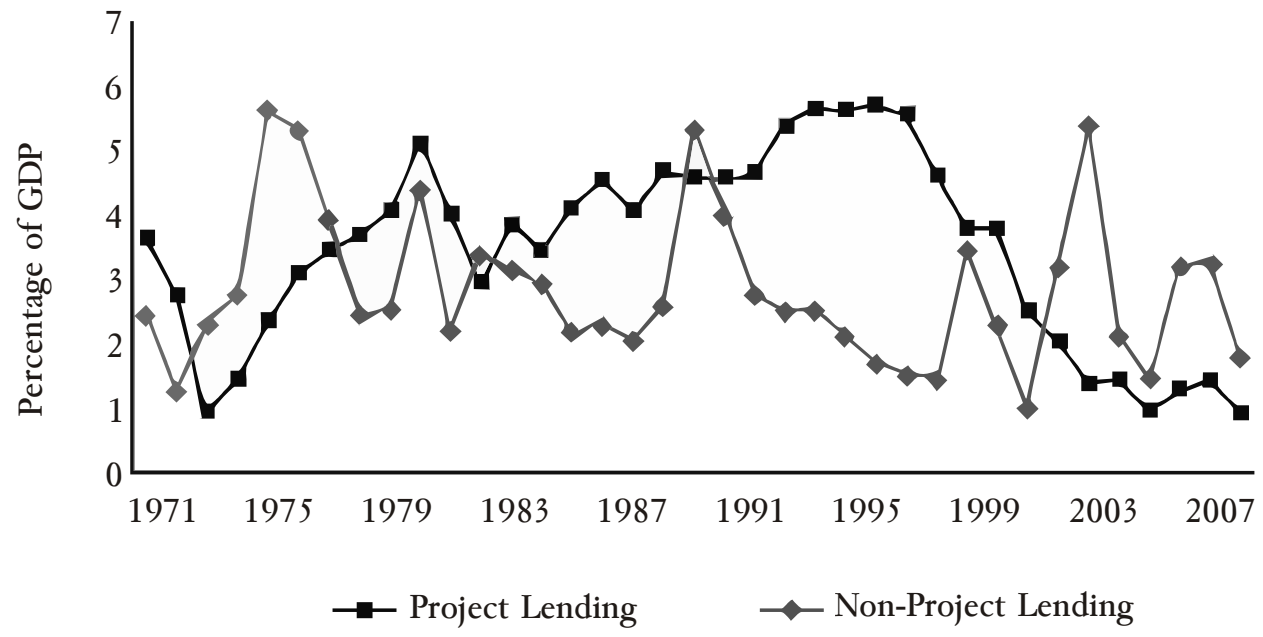

Under investment flows, portfolio flows are excluded due to their short-term nature. Further, data on FDI flows is cleaned up by filtering out privatization proceeds and including only the 'green-field' component (Figure 5). On the basis of the above discussion, the final estimate of the equilibrium RER includes worker's remittances, long-term project-based lending, and FDI flows less privatization proceeds.

Figure 5: FDI - Total and Adjusted for Privatization Proceeds (percent)

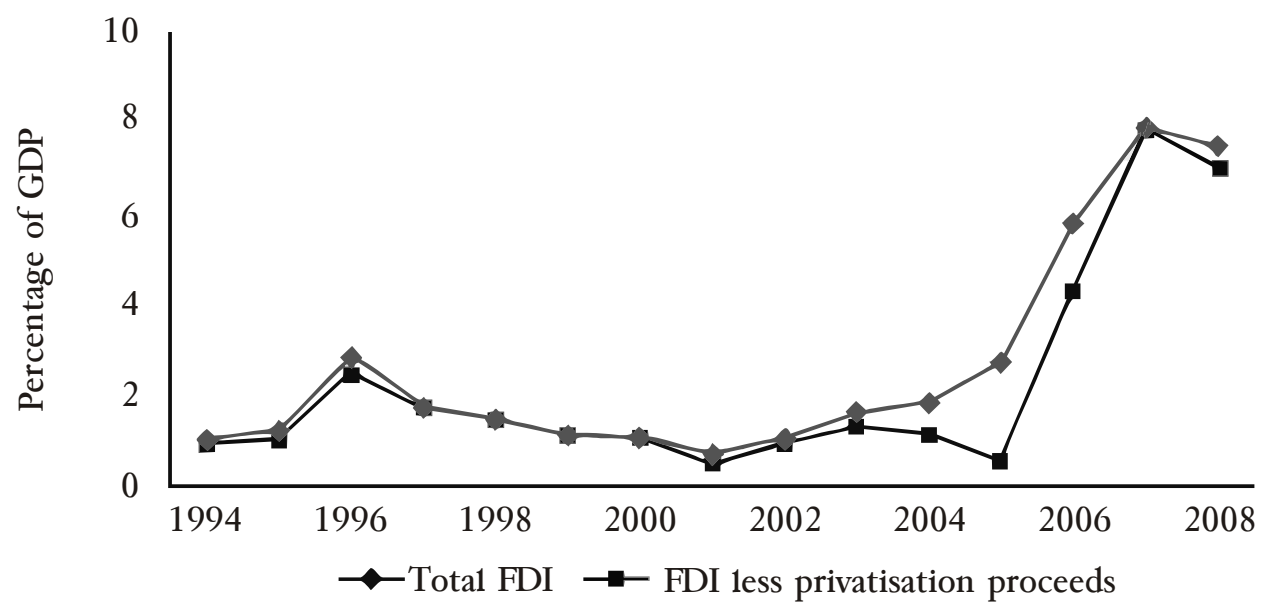




\section{Specifying an Empirical Model}

In what follows, an empirical model for estimating the equilibrium RER will be specified along with a discussion of the relationship between the RER and explanatory variables as predicted by theory a priori. ${ }^{13}$

$\operatorname{lnRER}=a+\beta_{1} \operatorname{lnTOT}_{t}+\beta_{2} \mathrm{LIB}_{t}+\beta_{3} \operatorname{lnGC}_{t}+\beta_{4} \mathrm{AST}_{t}+\beta_{5} \mathrm{FDI}_{t}+$ $\beta_{6} \mathrm{REMIT}_{\mathrm{t}}+\tau \mathrm{D}+\mu_{\mathrm{t}}$

where:

- TOT, terms of trade

- LIB, liberalization index (X+IM)/GDP

- GC, government spending

- AST, foreign project-based assistance as a \% of GDP

- FDI, green field investment only, as \% of GDP

- REMIT, remittances as \% of GDP

- RER, real exchange rate

- $D=1$ for $1997, D=2$ for 2000 and $D=0$ otherwise $^{14}$

- $\alpha$, constant, $\beta$, long-run parameters

- Terms of trade are defined as the ratio of the domestic price of exports to the domestic price of imports. The final impact of an improvement in the terms of trade is likely to depend on the relative magnitudes of income and substitution effects. If the income effect dominates the substitution effect, an improvement in the terms of trade is likely to cause an appreciation in the RER. ${ }^{15}$

- Trade policy stance. An economy's trade policy stance is likely to have repercussions for the RER. For example, an increase in openness due to a reduction in trade restrictions like tariffs, taxes, subsidies, and quotas is likely to depreciate the RER. Due to the unavailability of data on trade restrictions, alternative proxies have been used in the

\footnotetext{
${ }^{13}$ A detailed description of each variable, its definition and source is given in Table I, Appendix A.

${ }^{14}$ In the aftermath of Pakistan's nuclear tests in May 1997 followed by economic sanctions, the nominal exchange rate depreciated sharply from Rs43/US\$ to Rs50/US\$ in 1998. In 2000, a shift in the exchange rate regime from a managed float to a free floating regime led to the sharp depreciation of the nominal exchange rate from Rs51/US\$ to Rs58/US\$.

${ }^{15}$ An improvement in terms of trade, with the income effect outweighing the substitution effect implies that people have more to spend, which increases the demand for nontradables, and bids up prices in the nontradable sector. However, since the price of tradables is fixed by world prices, the RER appreciates.
} 
literature. Following Cottani, Cavallo, and Khan (1986), an 'openness' measure (defined as the ratio of imports plus exports over GDP) is used as a proxy for Pakistan's trade policy stance.

- Government consumption. An increase in the government consumption of nontradable goods is likely to increase demand for them, raising their price, and hence leading to an RER appreciation. Due to the unavailability of data on government consumption of nontradable goods, total government consumption is commonly used as a proxy for this measure [Edwards (1989)].

- Capital inflows. An increase in capital inflows is likely to appreciate the RER. Alternatively, an increase in capital controls is likely to depreciate the RER. The literature shows how different ratios of capital flows to GDP have been used to capture this measure. For example, Edwards (1989) uses the lagged ratio of net capital flows to GDP; Schafer (1989) uses net borrowing as a proportion of GDP as a proxy for capital control; Afridi (1995) uses the sum of net transfers (both private and official sources), net FDI, net portfolio investment, long-term capital flows, and short-term capital flows as a proportion of GDP to proxy for capital inflows to Pakistan. In this study, as discussed previously, a disaggregated measure of capital flows has been specified which entails remittances, FDI, and long-term project lending as a percentage of GDP.

\section{Exchange Rate Policy and Macroeconomic Fundamentals: A Brief Historical Review}

Historically, Pakistan has experimented with various exchange rate regimes. At the country's inception, a fixed exchange rate regime was followed: the value of the peg was fixed at Rs 4.76 to US\$1. In the face of rising deficits after the separation of East Pakistan, the nominal exchange rate was depreciated and the new peg set at Rs11 to US\$1. In 1982, Pakistan switched from a fixed exchange rate regime to a managed float. This shift in policy was followed by the significant depreciation of the nominal exchange rate from Rs10/US\$ in 1982 to approximately Rs50/US\$ in 1999. Since 2000, Pakistan has been following a freely floating exchange rate regime. Table-II, Appendix A, illustrates how the nominal exchange rate has evolved over time.

Trends in the RER are depicted in Figure 6. Since 1982, the RER appears to be following a depreciating trend, particularly in 1971, when the value of the peg was revised, and in 1982 and 2000, both years denoting a shift in the exchange rate regime. Post-2000, the RER appears to be appreciating in value. 
Figure 6: Real Exchange Rate

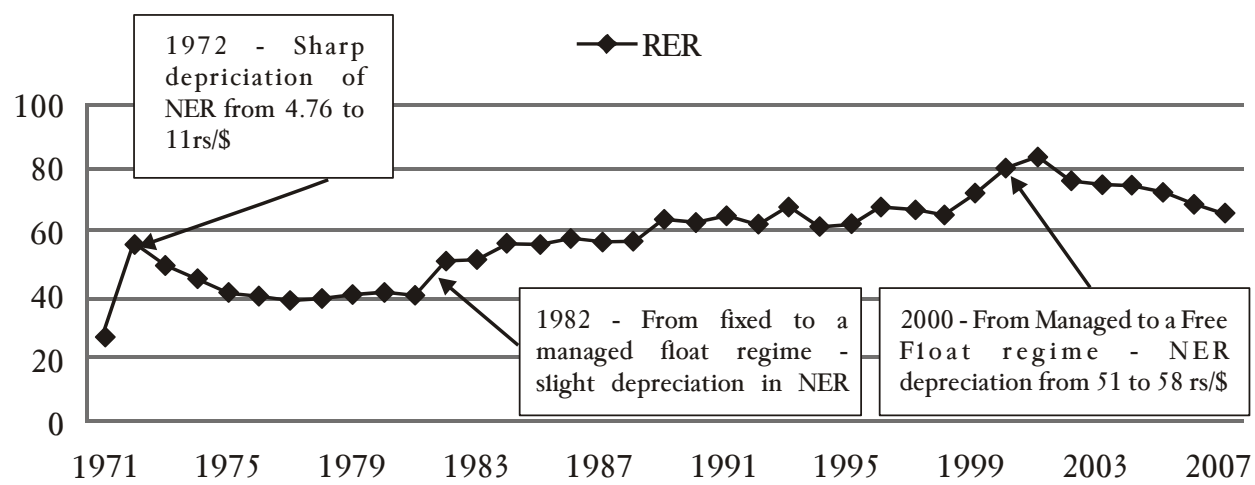

Source: Authors calculations based on IFS database, Handbook of Statistics (2005) and Pakistan Economic Survey (2007-08).

Figure 7 illustrates trends in capital flows-remittances, project lending, and FDI as a percentage of GDP. Since its inception, FDI flows have always been less than US\$100 million. This trend persisted until FY1985. Between FY1986 and FY1995, FDI flows were less than US\$500 million. In FY1996, FDI flows reached US\$1 billion. Between FY1997 and FY2004, flows were less than US\$1 billion. Since FY2005, FDI flows have exceeded US\$1 billion every year and, on average, Pakistan has been receiving about US\$4 billion in FDI flows annually. This has increased from approximately US\$1 billion in FY2005 to approximately US\$5 billion in FY2008. In percentage terms, since FY2005, FDI flows have reached about 5\% of GDP.

Figure 7: Capital Flows over Time

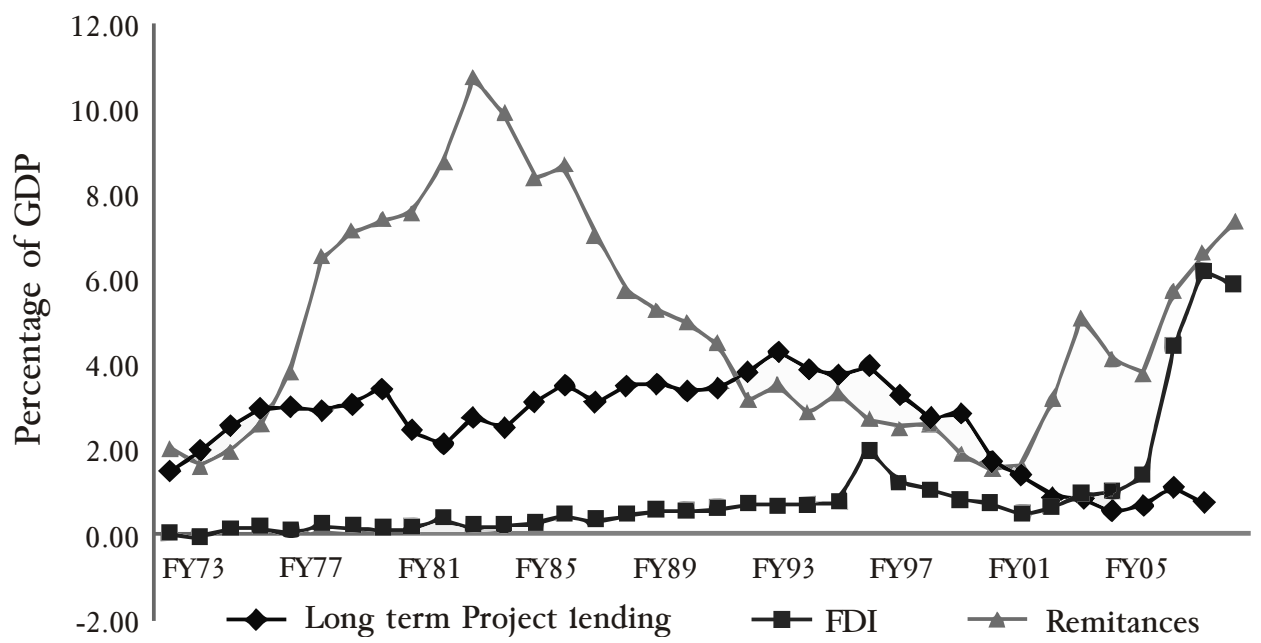

Source: Handbook of Statistics (2005) and Pakistan Economic Survey (2007-08). 
Official State Bank figures on remittances commence from 1973. During the 1970s, average remittances were less than US\$1 billion (approximately US\$700 million). During the 1980s, average remittances received per year came to approximately US\$2 billion, peaking in FY1983, when they were approximately US\$3 billion. During the 1990s, average remittance flows declined to about US\$1.5 billion per year. Post-9/11, there has been a sharp increase in remittances. Remittance flows increased from about US\$1 billion in FY2001 to approximately US\$7 billion in FY2008. Between FY2002 and FY2008, Pakistan received an average of about US\$4.5billion.

Official State Bank figures on long-term project-based assistance commence from 1961. Prior to FY1982, foreign economic assistance was always less than US\$1billion. Since then, it has ranged between US\$1 billion and US\$3 billion annually. During the 1980s, the average received per year was US\$1.5 billion; during the 1990 s, US $\$ 2.4$ billion, and since 2000 , the average per year has been approximately US\$2 billion.

Figure 8 illustrates trends in government consumption, terms of trade, and openness in Pakistan. Total government spending as a percentage of GDP remained stagnant through much of the 1980s after which it rose. During the 1970s, average government spending was US\$2.5 billion; and during the 1980s, approximately US\$7 billion. Between FY1995 and FY2001, government spending remained largely stagnant at US\$12 billion. Since FY2001, average government spending has been approximately US $\$ 20$ billion. Since FY2002, it has been on the rise, increasing from approximately US\$14 billion in FY2002 to about US\$30 billion in FY2008.

Figure 8: Trends in Terms of Trade, Openness and Government Spending

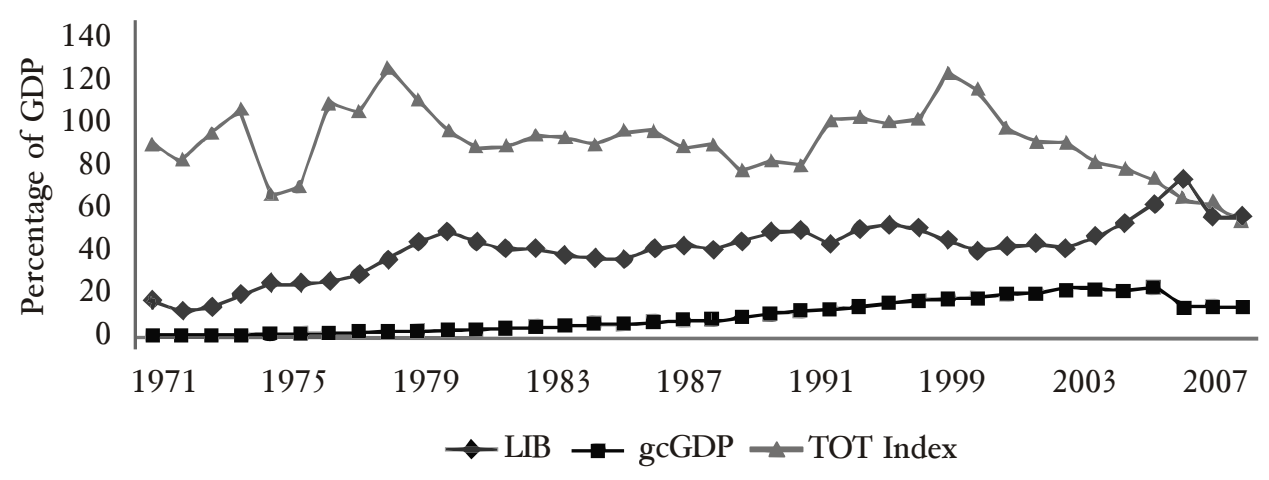

Source: Handbook of Statistics (2005) and Pakistan Economic Survey (2007-08).

Both exports and imports have consistently increased over time. However, the share of exports in total trade has historically always been 
small relative to imports. For instance, in FY2008, exports totaled US\$13 billion while imports stood at approximately US\$24 billion. Since FY2005, Pakistan has witnessed a deteriorating trade balance as the gap between exports and imports has continued to increase.

Since 2000 , the terms of trade have deteriorated, overall trade as a percentage of GDP has increased, and government spending as a percentage of GDP has decreased since 2005. All these trends should be consistent with a depreciating RER as predicted by theory a priori.

\section{Methodology}

As a first step, the time series properties of the RER and relevant fundamentals will be examined. If variables are stationary, ordinary least squares estimation will yield accurate results and standard $\mathrm{t}$ and $\mathrm{F}$ tests can be used for inference. If variables are nonstationary, it becomes necessary to resort to an alternative means of estimation to avoid any spurious correlation. Furthermore, the usual $t$ and $F$ statistics no longer remain valid and therefore cannot be used to derive meaningful results. Thus, analyzing the time series properties of the variables in question will help determine an appropriate estimation technique. To this effect, an Augmented DickeyFuller (ADF) test will be used.

Since this study employs a long-run focus, the second step will be to establish the presence of a long-run equilibrium relationship between the RER and set of explanatory variables discussed above. The Johansen-Julies test of co-integration will be used to achieve this.

The third step will entail estimating a vector error correction model (VECM) to obtain long-run parameters for the fundamentals [i.e., the $\beta$ s in equation (9) and the $\Pi$ - vector of coefficients of explanatory variables in equations (10a) and (10b)].

$$
\begin{aligned}
& \Delta y_{t}=\sum_{j=1}^{p-1} \gamma_{j} \Delta y_{i-j}+\sum_{j=0}^{p-1} \delta_{j} \Delta x_{i-j}+\varphi\left[y_{i-1}-\left\{\gamma+\pi_{i} x_{i-1}\right\}\right]+\varepsilon_{i} \\
& y_{t}=\gamma+\pi_{i} x_{i}+u_{i} \quad \text { where } u_{i} \sim I(0)
\end{aligned}
$$

where $y=$ real exchange rate

$x=$ vector of explanatory variables (tot, gc, lib, asst, remit, fdi) 


$$
\begin{aligned}
& \varphi=\text { speed of adjustment to long-run relationship } \\
& \Pi=\text { long-run coefficients } \\
& {[]=\text { long-run relationship - equilibrium error }}
\end{aligned}
$$

Estimating the long-run parameters is useful for two reasons. First, they will help establish whether or not the direction of the relationships between the RER and the fundamentals is in line with theory. Second, by giving the precise magnitudes of the relationships between the dependant variable and each of the explanatory variables, a measure for the equilibrium RER will be obtained.

In the fourth step, a misalignment index will be used (equation 11) to calculate the extent of deviation (or otherwise) in the real exchange for the period 1972-2007. An index value of zero implies that the actual RER is fairly valued. A positive (negative) index value implies that the actual RER is undervalued (overvalued) relative to the equilibrium rate.

Misalignment Index $=\frac{R E R_{t}-E R E R_{t}}{E R E R_{t}}$

\section{Estimation Results}

\section{Step 1}

The Augmented Dickey-Fuller (ADF) test tests the null hypothesis of the presence of a unit root against the alternative that the series does not have a unit root. This test is applied to each variable (in levels) and the resulting test statistic compared with ADF critical values. For each variable, the test statistic is less than the ADF critical value. Consequently, one fails to reject the null hypothesis that the series has a unit root (i.e., it is nonstationary). Similarly, applying the test to first differences yields a test statistic that is greater than the critical value for each variable (Table2 ). Therefore, at a $5 \%$ level of significance, it can be concluded that all variables are nonstationary in levels, but stationary in first differences. In other words, all variables are integrated to the order of 1 , i.e., I(1). 
Table-2: Order of Integration Test, 1972-2007

\begin{tabular}{lcc}
\hline \multicolumn{1}{c}{ Variable } & $\begin{array}{c}\text { ADF Test } \\
\text { (Levels) }\end{array}$ & $\begin{array}{c}\text { ADF Test } \\
\text { (First Difference) }\end{array}$ \\
\hline LnRER & $-2.906(2)$ & $-4.315(2)$ \\
LnGC & $-1.856(2)$ & $-4.319(2)$ \\
LnTOT & $-3.251(2)$ & $-4.209(2)$ \\
LIB & $-3.255(1)$ & $-4.261(2)$ \\
ASST(\% of gdp) & $-1.466(2)$ & $-4.953(1)$ \\
REMIT(\% of gdp) & $-1.962(2)$ & $-3.594(1)$ \\
FDI(\% of gdp) & $-2.624(2)$ & $-4.953(1)$ \\
Critical Values - at 1\% & -4.143 & -3.577 \\
Critical Values - at $5 \%$ & -3.497 & -2.928 \\
Critical Values - at 10\% & -3.178 & -2.599 \\
\hline
\end{tabular}

Notes: Number of lags in parenthesis.

\section{Step 2}

Next, we check for a stable long-run relationship between the variables. Section 3 makes the case for excluding temporary and unsustainable flows when analyzing the RER from a long-term perspective. Therefore, to begin with, the objective was to see whether estimation results are in line with the intuitive predictions outlined in Section 3. Unsustainable flows (portfolio, short-term, and nonproject-based lending) are incorporated and the Johansen-Julius test applied to all variables. Based on the estimation results, we fail to reject the null hypothesis of no long-run relationship among variables.

Next, the three categories of unsustainable flows are dropped. The Johansen-Julieus test is applied to verify the presence of a stable long-run relation among these variables. This time, the trace test indicates the presence of one co-integrating vector which implies that a stable long-run relationship exists among the variables (Table-3). 
Table-3: Number of Co-Integrating Relationships

\begin{tabular}{ccc}
\hline $\begin{array}{c}\text { Number of Hypothesized } \\
\text { Co-integrating Equations }\end{array}$ & Trace Statistic & 5\% Critical Value \\
\hline None & 196.3099 & 124 \\
At most 1 & 74.8625 & 94.15 \\
\hline
\end{tabular}

Notes: Using Johansen's Approach, the trace test indicates the presence of one co-integrating relationship among the variables at a $5 \%$ level of significance.

\section{Step 3}

Given that a long-run equilibrium relationship exists among the variables discussed above, a VECM is estimated [equation (12)] to determine the long-run parameters for these variables and establish weak exogenity of the explanatory variables so as to rule out reverse causality from the dependant variable to the right-hand side variables. In a VECM, a variable can be concluded to be weakly exogenous if the adjustment parameter for its equilibrium error is statistically insignificant.

$$
\begin{aligned}
& \text { ERER }=-0.05-0.345^{*} \mathrm{GC}-0.0596^{*} 1 \mathrm{TOT}+0.998^{*} \mathrm{LIB}-3.53^{*} \mathrm{ASSTgdp}- \\
& 2.412^{*} \text { REMITgdp }-30.08 * \text { FDIgdp }+0.0011^{*} \mathrm{D}
\end{aligned}
$$

Table-4 indicates that all variables are significant at a $5 \%$ level. Terms of trade, openness, remittances, and project lending are weakly exogenous (implying that reverse feedback effects from the RER to these variables can be ruled out). The negative sign for all categories of capital flows are in line with Dutch Disease theory. More specifically, our results predict that a one-unit increase in long-term project lending (as a percentage of GDP) will appreciate the RER by $3.5 \%$, ceteris paribus. A one-unit increase in remittances (as a percentage of GDP) will appreciate the RER by approximately $2.5 \%$, ceteris paribus. The negative coefficient of the FDI term is in line with theory but the direction of the relationship between the RER and FDI flows could not be established. Overall, it can be concluded that the Dutch Disease hypothesis holds, and that capital flows have been a disease rather than a cure for the Pakistani economy.

Further, the signs for openness and government spending are also in line with the theory. Results predict that a one-unit increase in the openness ratio will depreciate the RER by approximately $1.0 \%$, ceteris paribus. As mentioned previously, the effect of terms of trade on the RER depends on the relative magnitude of income and substitution effects. The negative sign for the terms of trade coefficient illustrates that in Pakistan the income effect 
dominates the substitution effect. According to our results, a one-unit improvement in terms of trade appreciates the RER by approximately $0.05 \%$, ceteris paribus. These findings are summarized in Figure 9.

Table-4: ECM Long-Run Parameter Estimates for Pakistan

\begin{tabular}{llll}
\hline & \multicolumn{1}{c}{ Coef. } & $Z$ & $P>|\mathbf{z}|$ \\
\hline Constant & -0.052 & & \\
LnGC & $-0.345(0.0117)$ & -29.51 & 0.000 \\
LnTOT & $-0.0596(0.022)$ & -2.66 & 0.008 \\
LIB & $0.998(0.3809)$ & 2.62 & 0.009 \\
ASST(\% of gdp) & $-3.53(0.804)$ & -2.77 & 0.000 \\
REMIT(\% of gdp) & $-2.412(8.55)$ & 3.00 & 0.006 \\
FDI(\% of gdp) & $-30.0756(1.279)$ & 3.52 & 0.003 \\
\hline
\end{tabular}

Notes: The model employs 4 lags, a constant and no trend.

With an R square of 0.741 -implying that approximately $74 \%$ of the variation in the dependant variable is explained by variation in the explanatory variables-it can be concluded that the model has a reasonable fit. The dummy variable is also significant, implying that events in 1997 and 2000 were statistically significant in influencing the RER and hence resulted in an intercept shift. 
Figure 9:
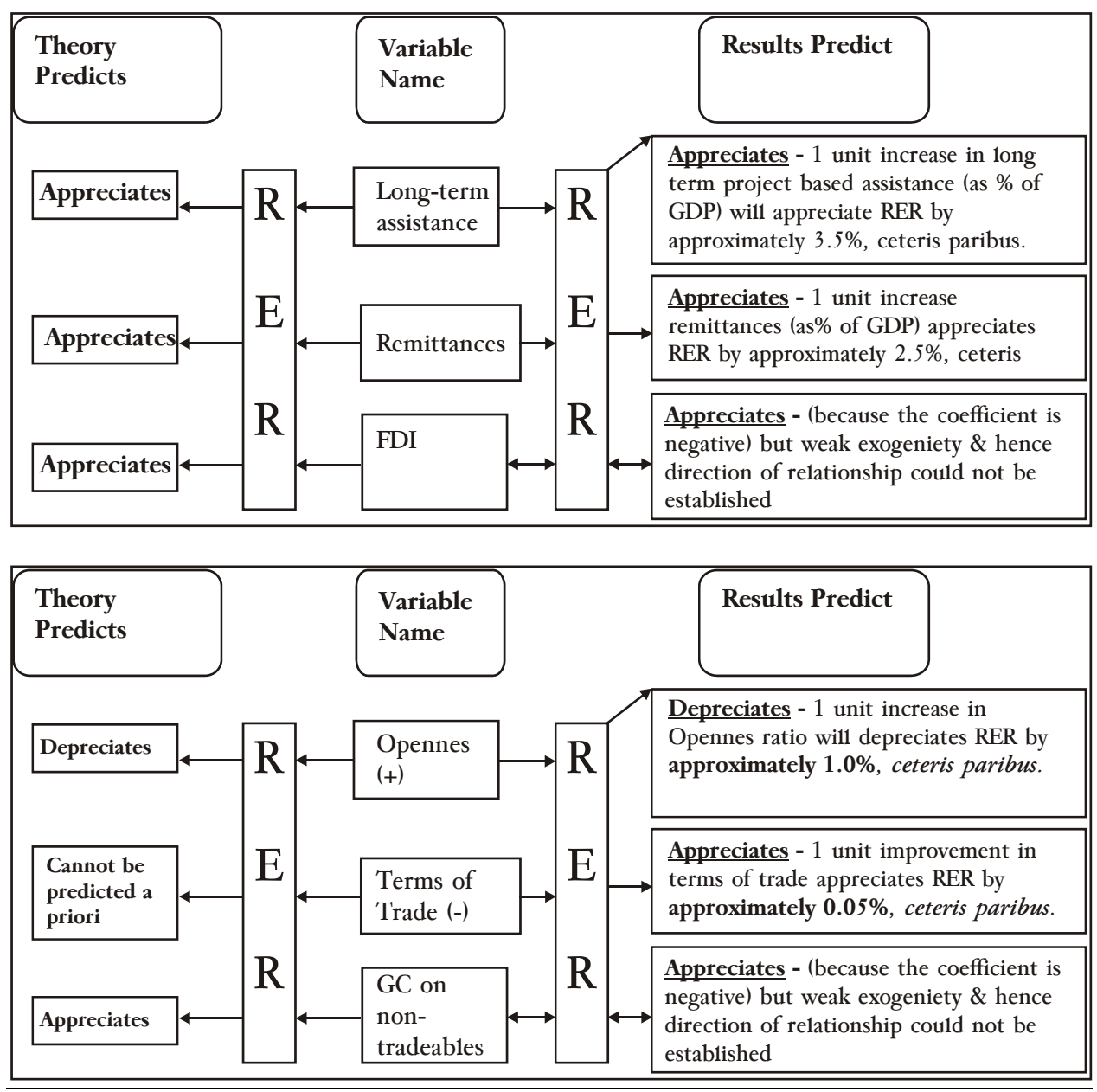

\section{Step 4}

Based on equation (11), a misalignment index is calculated and plotted against time (Figure 10). The RER has remained overvalued for the most part over the sample period ranging from 1971 to 2007. Estimation results suggest that on average, the RER has remained overvalued by approximately $5 \%$ during the 1970 s, $7 \%$ during the 1980 s, 3\% during the 1990 s, and $11 \%$ during the current decade. Clearly there has been an increasing trend in RER overvaluation (Figure II, Appendix A). In particular, three instances of overvaluation warrant deeper discussion. The first one occurred from 1977 to 1983 and the second one from 1996 to 1999, while the third one was initialized in 2002 and continues to be underway. 
The first overvaluation episode can be attributed to a rapid increase in remittances over the given time period. Figure 7 illustrates that, after 1977, remittances as a percentage of GDP started picking up rapidly and reached a record peak in 1983, when this ratio was approximately as high as $11 \%$ of GDP. The second overvaluation episode during the late 1990s can be attributed to the turn of events in the wake of nuclear tests conducted under the Nawaz Sharif regime. As a response to economic sanctions, the government froze residents' foreign currency deposits which ranged between 7 and 9\% of GDP over 1997 and 1998 (Table-III, Appendix A), and fixed the nominal exchange rate at Rs46/US\$. The third overvaluation episode started post $9 / 11$ and still continues, although the pace of real exchange overvaluation seems to have declined.

The current overvaluation episode can be attributed to a sharp upsurge in capital flows in the wake of $9 / 11$, specifically to a large increase in remittances since FY2002 and FDI flows since FY2005. Remittance flows increased from about US\$1 billion in FY2001 to approximately US\$7 billion in FY2008. Between FY2002 and FY2008, Pakistan received an average of about US\$4.5 billion (Figure 7). Likewise, FDI flows have since FY2005 exceeded US\$1 billion and on average Pakistan has received about US\$4 billion in FDI flows annually. This has increased from approximately US\$1 billion in FY2005 to approximately US\$5 billion in FY2008 (Table-5). While the terms of trade have also deteriorated over this time period, [declined from 90 in 2001 to approximately 55 in 2008 (Figure 8)], the appreciating effects of an upsurge in capital flows seems to have far outweighed the depreciating impact of a deterioration in terms of trade.

Figure 10: Misalignment Index (\%)

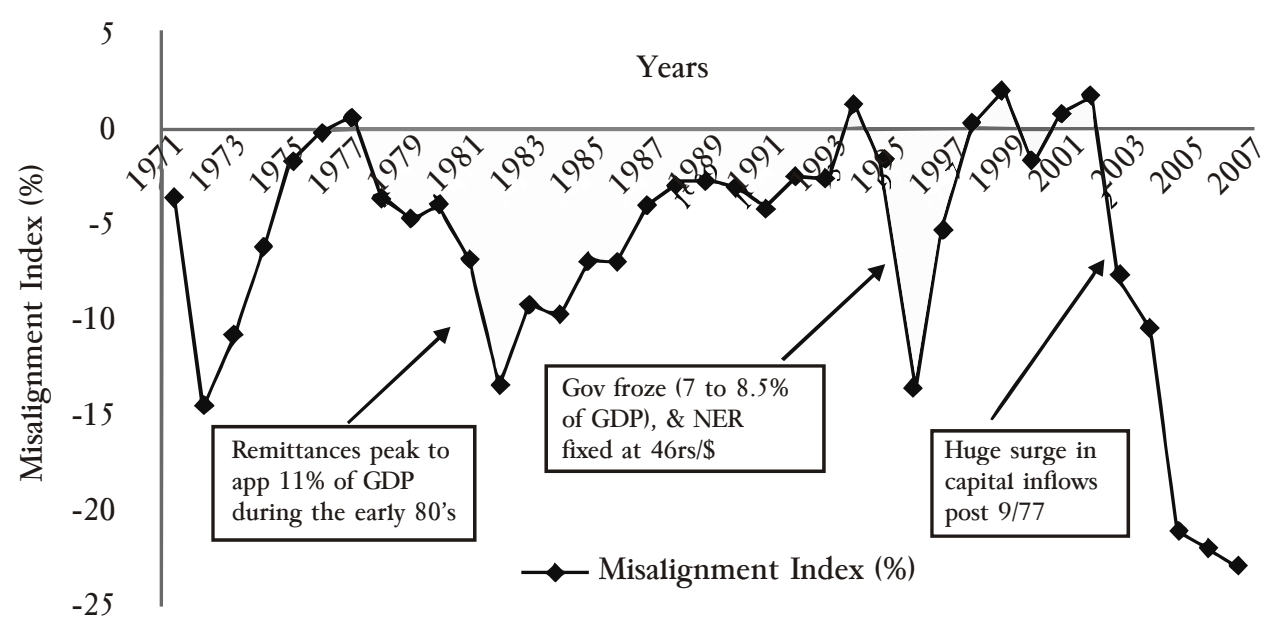


Table-5

\begin{tabular}{lcc}
\hline Year & Total FDI (million \$) & Privatization Proceeds (million \$) \\
\hline 1994 & 354.1 & 64.83 \\
1995 & 442.4 & 148.99 \\
1996 & $1,101.7$ & 307.77 \\
1997 & 682.1 & - \\
1998 & 601.3 & - \\
1999 & 472.3 & - \\
2000 & 469.9 & - \\
2001 & 322.5 & 135.95 \\
2002 & 484.7 & 63.25 \\
2003 & 798 & 194.75 \\
2004 & 949.4 & 477.29 \\
2005 & 1,524 & $1,625.73$ \\
2006 & 3,521 & 1,540 \\
2007 & 5,140 & 266 \\
2008 & 5,153 & 133 \\
\hline
\end{tabular}

Source: Economic Survey of Pakistan (various issues).

\section{Step 5}

The Dutch Disease hypothesis holds that capital flows have played a significant role in persistent overvaluation of the RER since 2001. In particular, remittances and FDI flows seem to have contributed much to the high degree of misalignment since 2001. A shortcoming of the model as specified in equation (9), is that, while the sign for FDI is in line with theory, a causal link from FDI to the RER could not be established. This brings into question the suitability and accuracy of the model as specified in equation (9). Therefore, as a logical next step, a variant of the model is estimated. In what follows, the modified version of the model along with estimation results will be presented:

$\operatorname{lnRER}_{t}=a+\beta_{1} \operatorname{lnTOT}_{t}+\beta_{2} \mathrm{LIB}_{t}+\beta_{3} \operatorname{lnGC}_{t}+\beta_{4} \mathrm{CAP}_{t}+$ $\beta_{5} \mathrm{REMIT}_{\mathrm{t}}+\tau \mathrm{D}+\mu_{\mathrm{t}}$ 
Where

- TOT, terms of trade

- LIB, liberalization index $(\mathrm{X}+\mathrm{IM}) / \mathrm{GDP}$

- GC, government spending

- CAP, sum of long-term project lending and FDI flows as a \% of GDP

- REMIT, remittances as \% of GDP

- RER, real exchange rate

- $\mathrm{D}=1$ for $1997, \mathrm{D}=2$ for 2000 and $\mathrm{D}=0$ otherwise

$-\alpha$, constant, $\beta$, long-run parameters

The maximum Eigen value test indicates the presence of one longrun equilibrium relationship among the variables at a $5 \%$ level of significance (Table-6). Again, the signs for all variables are in line with theory such that an increase in capital flows (i.e., remittances, project lending, or FDI flows), government spending on nontradables, and an improvement in terms of trade are expected to appreciate the RER while an increase in openness is predicted to depreciate the RER.

Table-6

\begin{tabular}{cccc}
\hline Hypothesized & Max-Eigen & $\mathbf{0 . 0 5}$ & \\
\hline No. of CE(s) & Statistic & Critical Value & Prob.** \\
\hline None ${ }^{*}$ & 41.76854 & 40.07757 & 0.0320 \\
At most 1 & 29.40518 & 33.87687 & 0.1559 \\
At most 2 & 21.40909 & 27.58434 & 0.2522 \\
At most 3 & 17.38956 & 21.13162 & 0.1544 \\
At most 4 & 10.98621 & 14.26460 & 0.1549 \\
\hline
\end{tabular}

The next step is to establish causality between the dependant variable and the right-hand side variables. Consequently, a VECM is estimated (equation 13) to establish weak exogenity (or otherwise). Equilibrium error adjustment parameters for CAP and REMIT, are insignificant implying that this time, all categories of capital flows are 
weakly exogenous. ${ }^{16}$ In particular, a one-unit increase in remittances (as a percentage of GDP) is expected to appreciate the RER by approximately $2.54 \%$, ceteris paribus. Note that this result is not very different from what was estimated in the previous model. Likewise, a one-unit increase in capital flows (i.e., due to an increase in project lending or adjusted FDI or both), the RER is expected to appreciate by approximately $7 \%$.

ERER $=-2.094-0.359^{\circ} \mathrm{GC}-0.0165^{*} 1 \mathrm{nTOT}+2.311^{\circ} \mathrm{LIB}-6.810^{*} C A P-$ 2.54*REMIT $-0.05^{\circ} \mathrm{D}$

\section{Conclusion}

This paper has calculated the equilibrium RER and subsequent extent of overvaluation in Pakistan for the period 1971 to 2007 as a function of various macroeconomic fundamentals, as suggested in the literature by Edwards (1988, 1989, 1994), Elbadawi (1994), and Montiel (1997). Based on estimation results, it can be concluded that terms of trade, government spending in the nontradable sector, degree of openness, and capital flows are significant in determining the equilibrium exchange rate and in explaining the extent of deviation between the actual and equilibrium rate. This paper differs from existing studies by incorporating the Dutch Disease dimension and by placing special emphasis on the effect of capital flows on RER overvaluation. The findings suggest that

- The RER suffers from chronic overvaluation in Pakistan. In spite of filtering out unsustainable and temporary flows, overvaluation increased from $0.75 \%$ in 2001 to $22.9 \%$ 2007. An increase in remittances (between FY2002 and FY2008) and a sharp rise in FDI flows (between FY2005 and FY2008) are among the main factors that have contributed to this misalignment.

- The Dutch Disease hypothesis holds in the case of Pakistan. All categories of capital flows are statistically significant, weakly exogenous, and the sign preceding their coefficients negative, implying that increases in capital flows exert significant appreciating effects on the RER-a finding that goes some way toward explaining Pakistan's poor experience with sustaining macroeconomic stability and its poor performance in the tradable sector relative to the nontradable sector.

\footnotetext{
${ }^{16}$ CAP: long run adjustment parameter: 0.04, $\mathrm{t}$ statistic: [0.88138].

REMIT: long run adjustment parameter: -0.011301 , $t$ statistic: [-0.23042] $\mathrm{R}^{2}$ is 0.699 .
} 
In light of these findings, we can conclude that capital flows have played a significant role in RER overvaluation-a finding that is instrumental in understanding the poor performance of the tradable sector. Given that this sector has the potential to improve the external account, if Pakistan wants to achieve inter-temporal solvency-i.e., the ability to sustain its current account deficits without defaulting on its debt-it must follow a proactive exchange rate policy to improve the competitiveness of its tradable sector and attract greater investment in manufacturing (textiles, cement, etc.) to reverse trends like the declining share of the textile sector in overall FDI. ${ }^{17}$

${ }^{17}$ Table IV (Appendix A) 


\section{References}

Afridi, U. (1995). Determining Real Exchange Rates. The Pakistan Development Review, 34(3) : 263-276.

Baffes, J., Elbadawi, I.A., and O’Connell, S.A. (1999). Single Equation Estimation of the Equilibrium Real Exchange Rate, in L.E. Hinkle, and P.J. Montiel (eds.), Exchange Rate Misalignment: Concepts and Measurement for Developing Countries, New York: A World Bank Research Publication, Oxford University Press, 405-464.

Cassel, G. (1916). The Present Situation of Foreign Exchange. Economic Journal, $26: 62-65$.

Casse1, G. (1981). Abnormal Deviations of International Exchanges. Economic Journal, 28 : 413-415.

Chishti, S., and Hasan, M.A. (1993). What Determines the Behaviour of Real Exchange Rate in Pakistan? The Pakistan Development Review, 32(4) : 1015-1028.

Domac, I. and Shabsigh, G. (1999). Real Exchange Rate Behavior and Economic Growth: Evidence from Egypt, Jordon, Morocco and Tunisia. IMF Working Paper, No: 40

Easterly, W. (2005). National Policies and Economic Growth. In Philippe Aghion and Steven Durlauf, editors, Handbook of Economic Growth, Elsevier.

Edward, S. (1994). Real and Monetary Determinants of Real Exchange Rate Behavior: Theory and Evidence from Developing Countries. Chapter 4, Williamson, John ed. (1994) Estimating Equilibrium Exchange Rates, Institute for International Economics: Washington.

Edwards, S. (1988). Real and Monetary Determinants of Real Exchange Behaviour: Theory and Evidence from Developing Countries. Journal of Development Economics, 29 : 311-341.

Edwards, S. (1989). Real Exchange Rates, Devaluation, and Adjustment: Exchange Rate Policy in Developing Countries. Cambridge, Mass.: MIT Press. 
Elbadawai, I. (1994). Real and Monetary Determinants of Real Exchange Rate Changes. In National Monetary Policies and the International Financial System, ed by R.Z. Aliber, University of Chicago Press.

Elbadawi, I., and Raimundo, S. (1994). Capital Flows and Long-Term Equilibrium Real Exchange Rate in Chile. Policy Research Working Paper : 1306.

Government of Pakistan, Government Pakistan Economic Survey (Various Issues). Islamabad: Finance Division, Economic Advisor's Wing.

Government of Pakistan, State Bank Annual Reports (Various Issues).

Hinkle, L.E., and Montie1, P.J (eds) (1999). Exchange Rate Misalignment, Concept and Measurement for Developing Countries, Oxford University Press.

Hussain, S. (2008). Sources of Real Exchange Rate Misalignment Evidence from Pakistan. SBP Working Paper Series, 26.

Illahi, Na., and Shendy, R. (2008). Do the Gulf Oil-Producing Countries Influence Regional Growth? The Impact of Financial and Remittances Flows. IMF Working Paper, WP/08/167.

Janjua, M.A. (2007). Pakistan's External Trade: Does Exchange Rate Misalignment Matter for Pakistan? The Lahore Journal of Economics, Special Edition.

Johnson, Simon H., Jonathan Ostry, and Arvind Subramanian (2007). The prospects for Sustained Growth in Africa: Benchmarking the Constraints. IMF Working Paper, 07/52.

Measurement for Developing Countries, New York: A World Bank Research Publication, Oxford University Press : 264-290.

Montie1, P.J. (1999). Determinants of the Long Run Real Exchange Rate: An Analytical Model. In L.E. Hinkle and P.J. Montiel (eds.), Exchange Rate Misalignment: Concepts.

Razin, O., and Collins, S. (1997). Real Exchange Rate Misalignment and Growth. NBER Working Papers, 6174.

Rodrik, D. (2008). The Real Exchange Rate and Economic Growth. John F. Kennedy School of Government. 
Siddiqui, R.A., Usman and Zafar, M. (1996). Exchange Rate Determination in Pakistan: A Simultaneous Equation Model. The Pakistan Development Review, Part II, 683-692.

Williamson, J. (1993). Equilibrium Exchange Rates: An Update. Memo, Institute for International Economics, Washington D, C

Williamson, J. (1994). Estimates of FEERs. In J. Williamson (ed.), Estimating Equilibrium Exchange Rates. Institute for International Economics: Washington, D.C. 
Appendix A

Figure I: Disaggregating Capital Inflows

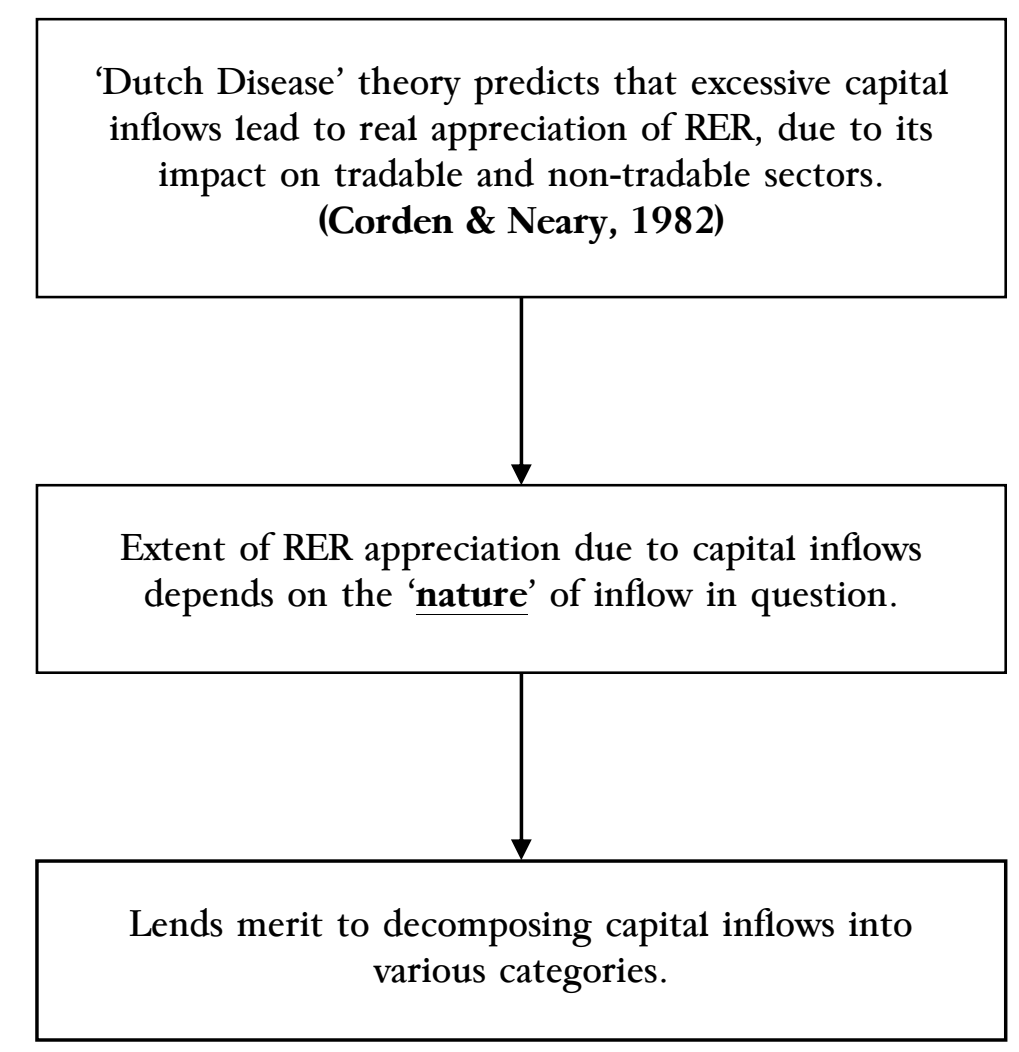

Figure II: Misalignment Index (\%)

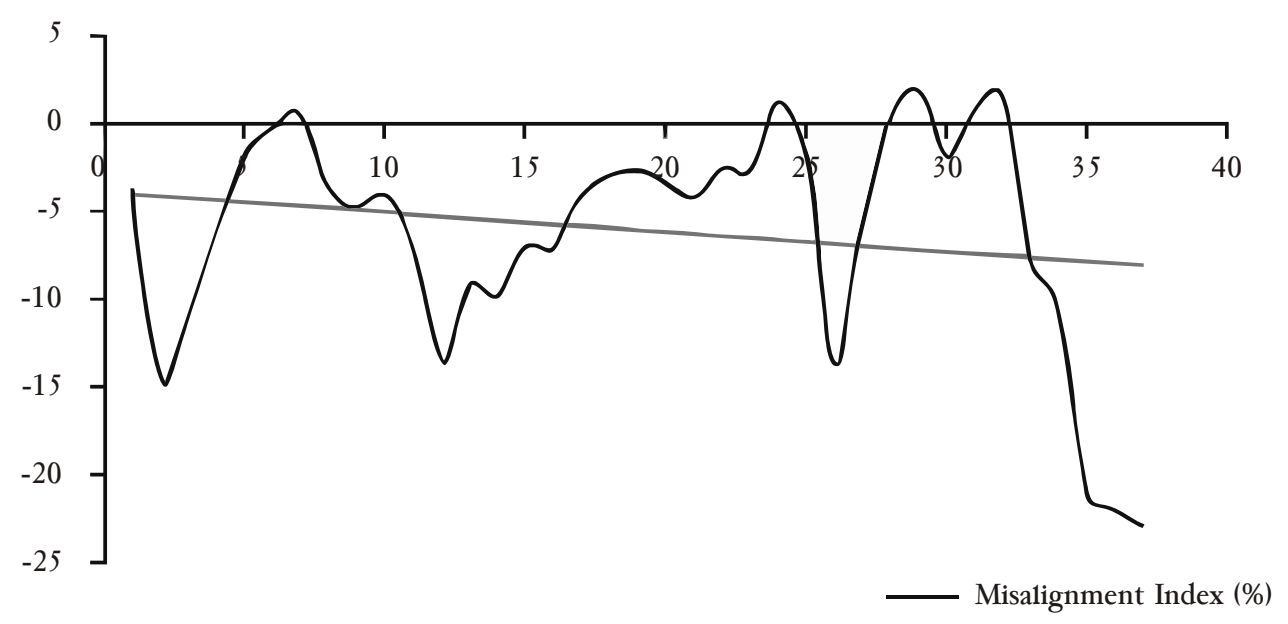




\section{Table-I}

\begin{tabular}{|c|c|c|}
\hline Variable & Definition & Source \\
\hline PER & $\begin{array}{l}\text { Real Exchange Rate }=E^{*}\{t / P n \\
\text { USWPI } \rightarrow \text { Pt } \\
\mathrm{CPH} \rightarrow \mathrm{Pt} \\
\mathrm{E} \rightarrow \text { nominal exchange rate }(\mathrm{rs} / \$)\end{array}$ & IMF Statistics Repository \\
\hline TOT & $\begin{array}{l}\text { Terms of Trade measured as the ratio } \\
\text { of a Unit value of Exports to a Unit } \\
\text { value of Imports }\end{array}$ & $\begin{array}{l}\text { Handbook of Statistics } \\
(2005), \text { SBP }\end{array}$ \\
\hline LIB & $\begin{array}{l}\text { Liberalization Index as a proxy for the } \\
\text { country's trade stance at each time } \\
\text { period } \\
\mathrm{LIB}=(\mathrm{EX}+\mathrm{IM}) / \mathrm{GDP}\end{array}$ & $\begin{array}{l}\text { Handbook of Statistics } \\
(2005), \text { SBP }\end{array}$ \\
\hline GC & $\begin{array}{l}\text { Total Government consumption } \\
\text { Spending } \\
\text { Proxy for government spending on } \\
\text { nontradables }\end{array}$ & $\begin{array}{l}\text { Handbook of Statistics } \\
(2005), \text { SBP }\end{array}$ \\
\hline $\mathrm{CF}$ & $\begin{array}{l}\text { Capital Inflows: } \\
\text { To include sustainable flows only, this } \\
\text { term has been disaggregated into } \\
\text { three subcategories: } \\
\text { 1) Project Based foreign } \\
\text { assistance which includes both } \\
\text { loans and grants. } \\
\text { 2) Foreign direct investment } \\
\text { flows less privatization } \\
\text { proceeds } \\
\text { 3) Remittances }\end{array}$ & \\
\hline
\end{tabular}


Table-II: Evolution of Nominal Exchange Rate in Pakistan 1947-2008

\begin{tabular}{|c|c|c|}
\hline Exchange Rate Regime & Date/Period & $\begin{array}{c}\text { Pak } \\
\text { Rupee/US\$ } \\
\end{array}$ \\
\hline \multirow[t]{3}{*}{ i) Fixed Exchange Regime (1947-1982 } & January 1955 onwards & 4.76 \\
\hline & November 1972 & 11 \\
\hline & February 1973 & 9.9 \\
\hline \multirow[t]{18}{*}{ ii) Managed Float Regime (1982-1998) } & January 1982 & 10.1 \\
\hline & $1981-82$ & 10.5535 \\
\hline & $1982-83$ & 12.7063 \\
\hline & $1983-84$ & 12.4838 \\
\hline & $1984-85$ & 15.1668 \\
\hline & $1985-86$ & 16.1391 \\
\hline & $1986-87$ & 17.1795 \\
\hline & $1987-88$ & 17.5994 \\
\hline & 1988-89 & 19.2154 \\
\hline & 1989-90 & 21.4453 \\
\hline & 1990-91 & 22.4228 \\
\hline & $1991-92$ & 24.8441 \\
\hline & $1992-93$ & 25.9598 \\
\hline & $1993-94$ & 30.1638 \\
\hline & $1994-95$ & 30.8507 \\
\hline & $1995-96$ & 33.5684 \\
\hline & 1996-97 & 38.9936 \\
\hline & $1997-98$ & 43.1958 \\
\hline iii) Two Tier Regime (1998-1999) & 1998-99 & $\begin{array}{l}50.0546 \\
46.7904\end{array}$ \\
\hline iv) Dirty Float Regime (1999-2000) & 1999-00 & 51.7709 \\
\hline \multirow[t]{8}{*}{ v) Free Float Regime (2000-2001) } & $2000-01$ & 58.4378 \\
\hline & 2001-02 & 61.4258 \\
\hline & $2002-03$ & 58.4995 \\
\hline & 2003-04 & 57.5740 \\
\hline & $2004-05$ & 59.3576 \\
\hline & $2005-06$ & 59.8566 \\
\hline & 2006-07 & 60.6342 \\
\hline & $2007-08$ & 62.5465 \\
\hline
\end{tabular}


Table-III: Foreign Currency Deposits 1993 to $2000^{18}$

\begin{tabular}{cc}
\hline Year & $\begin{array}{c}\text { Resident Foreign Currency Deposits } \\
\text { (as percent of GDP) }\end{array}$ \\
\hline 1993 & 2.30 \\
1994 & 3.30 \\
1995 & 3.62 \\
1996 & 4.71 \\
1997 & 7.08 \\
1998 & 8.54 \\
1999 & 4.44 \\
2000 & 2.15 \\
\hline
\end{tabular}

Source: Economic Survey 1999-2000.

${ }^{18}$ Handbook of Statistics (2005) and Pakistan Economic Survey (2007-08) 
Table-IV: Sector wise share in FDI

\begin{tabular}{lrrrrr} 
& & & & \multicolumn{2}{c}{ Percent } \\
\hline & FY04 & FY05 & FY06 & FY07 & FY08 \\
\hline I. Manufacturing & $\mathbf{1 7 . 9}$ & $\mathbf{1 6 . 8}$ & $\mathbf{7 . 1}$ & $\mathbf{1 8 . 8}$ & $\mathbf{1 1 . 9}$ \\
1. Transport equipment & 0.3 & 2.2 & 0.9 & 1.0 & 2.2 \\
2. Cement & 0.2 & 0.9 & 1.1 & 0.7 & 2.0 \\
3. Chemicals & 1.6 & 3.3 & 1.8 & 0.9 & 1.5 \\
4. Textiles & 3.7 & 2.6 & 1.3 & 1.2 & 0.6 \\
5. Others & 12.0 & 7.9 & 2.0 & 15.1 & 5.6 \\
II. Non-manufacturing & $\mathbf{8 2 . 1}$ & $\mathbf{8 3 . 2}$ & $\mathbf{9 2 . 9}$ & $\mathbf{8 1 . 2}$ & $\mathbf{8 8 . 1}$ \\
A-extractive industries & $\mathbf{2 1 . 4}$ & $\mathbf{1 2 . 8}$ & $\mathbf{9 . 2}$ & $\mathbf{1 1 . 2}$ & $\mathbf{1 3 . 2}$ \\
1. Oil \& Gas explorations & 21.3 & 12.7 & 8.9 & 10.6 & 12.3 \\
2. Others & 0.1 & 0.1 & 0.3 & 0.6 & 0.8 \\
B-Other services & $\mathbf{6 0 . 6}$ & $\mathbf{7 0 . 4}$ & $\mathbf{8 3 . 7}$ & $\mathbf{6 9 . 9}$ & $\mathbf{7 5 . 0}$ \\
1. Communications & 23.4 & 34.0 & 55.0 & 37.0 & 31.5 \\
A) Telecommunications & 21.8 & 32.4 & 54.1 & 35.6 & 27.9 \\
B) Information Technology & 1.4 & 1.5 & 0.9 & 1.4 & 3.5 \\
2. Financial business & 25.5 & 17.7 & 9.3 & 18.2 & 31.2 \\
3. Trade & 3.8 & 3.4 & 3.4 & 3.4 & 3.4 \\
4. Construction & 3.4 & 2.8 & 2.5 & 3.1 & 1.7 \\
5. Transport & 0.9 & 0.7 & 0.5 & 0.6 & 1.4 \\
6. Power & -1.5 & 4.8 & 9.1 & 3.8 & 1.4 \\
7. Others & 5.2 & 7.0 & 3.8 & 3.9 & 4.3 \\
\hline
\end{tabular}

Source: State Bank Annual Report 2007-08. 